\title{
Judicial Commission of the International Committee on Systematic Bacteriology VIIIth International Congress of Microbiology and Applied Bacteriology
}

\author{
Minutes of the Meetings, 17 and 22 August 1996, Jerusalem, Israel
}

Minute 1. Call to order. Chairman L. G. Wayne called the meeting to order at 9:00 a.m. on 17 August 1996 in the Holiday Inn Crowne Plaza Hotel.

Minute 2. Record of attendance. Present were R. R. Colwell, M. Goodfellow, P. A. D. Grimont, R. M. Kroppenstedt, D. P. Labeda (Executive Secretary-Treasurer, International Committee on Systematic Bacteriology [ICSB]), E. Stackebrandt (Secretary for Subcommittees, ICSB and Editor, International Journal of Systematic Bacteriology [IJSB]), J. T. Staley, H. G. Trüper (Chairman, ICSB), and L. G. Wayne (Chairman, Judicial Commission). Absent were W. Fredericksen (Editorial Secretary, ICSB). D. Jones, W. E. C. Moore (Vice-Chairman, Judicial Commission), F. Portaels, H. Prauser, J. M. Young, and G. A. Zavarzin.

Minute 3. Acceptance of alternates. L. G. Wayne was designated as the alternate for W. E. C. Moore, and R. R. Colwell was designated as the alternate for J. M. Young. No alternates had been designated for other absent members.

Minute 4. Minutes of the 1994 meeting. The minutes of the 1994 meetings held in Prague, Czech Republic, were accepted as published (Int. J. Syst. Bacteriol. 45:195-196, 1995), but with one correction: the words "and their orthographic variants" should be deleted from the end of Minute 15.

Minute 5. Adoption of the agenda. The agenda was adopted as circulated.

Minute 6. Matters arising from the minutes of the 1994 meeting. Minute 15 reported a discussion of the desirability and feasibility of establishing lists of orthographic variants of bacterial names in the IJSB. It was agreed that there be no formal effort to create a complete master list of such variants, but that the editor of the IJSB will advertise the journal's willingness to accept examples from contributors in the field and publish them in the ongoing list.

Minute 7. Appointment of a nominating committee. Noting that the Chairman and Vice-Chairman of the Judicial Commission will have completed their terms of service at the end of the Jerusalem meeting, the Chairman appointed a nominating committee consisting of M. Goodfellow, H. G. Trüper, and L. G. Wayne to nominate candidates for these positions.

Minute 8. Action on proposals to amend the Bacteriological Code. Two proposals to amend the Bacteriological Code (1990 revision) were presented.

(i) Proposal to add an Appendix to the Bacteriological Code establishing the provisional category Candidatus. Minute 9 of the minutes of the 1994 meeting in Prague introduced a recommendation that a new category of indefinite rank (Candidatus) be established for certain putative taxa that could not be described in sufficient detail to warrant establishment of a novel taxon. Subsequently Murray and Stackebrandt (Int. J. Syst. Bacteriol. 45:186-187, 1995) published a Taxonomic Note proposing the establishment of the provisional status Candidatus for incompletely described procaryotes. The Judicial Commission considered the proposal and recommended one change in wording: in Table 1, for the Order of mention "Cultivation" the Example responses should be changed to read "Not Cultivated or Can Not be Sustained in culture for more than a few serial passages." With that amendment, the Commission unanimously voted to recommend to the ICSB that this Taxonomic Note be adopted as an Appendix to the International Code of Nomenclature of Bacteria.

(ii) Proposal to require deposition of type strains of cultivable bacteria. In response to minute 12 of the 1994 meeting and to a Taxonomic Note on patent strains by D. Labeda et al. (Int. J. Syst. Bacteriol. 45:868-869, 1995), R. G. E. Murray has proposed (Int. J. Syst. Bacteriol. 46:831, 1996) that the Bacteriological Code be amended to require deposition of type strains in recognized culture collections. After reviewing the proposal, the Judicial Commission made the following changes in the wording of the proposal.

Rule 30(3) line 5. Change "... from which subcultures would be available." to "... from which subcultures must be available."

Rule 30(3). Delete last sentence reading "If the species is noncultivable, then type material of a recognizable form must be deposited and/or a photograph or illustration must be included in the description."

Rule 30(4), line 5, change ".. .awarded and subcultures. .." to read "... awarded or subcultures...."

Rule 30(4). Add the following sentence to this paragraph. "Any type strain for which a patent is pending must be so identified when the name is proposed."

With these modifications, the Commission unanimously voted to recommend to the ICSB that this amendment to the International Code of Nomenclature of Bacteria be adopted.

(iii) In view of the amendments approved in (i) and (ii), members of the Commission expressed a belief that the last paragraph of Rule 18a and Rule $18 \mathrm{f}$ of the present version of the Bacteriological Code were no longer appropriate. The Commission therefore instructed the Rules Revision Committee of the Commission to draft an amendment to delete these two texts and substitute a Recommendation that the Candidatus mechanism be applied in such cases.

Minute 9. Other matters relating to the Bacteriological Code. The Judicial Commission considered the draft of the proposed "universal" code of bionomenclature (Biocode) that had been made available. It was agreed that it would be desirable to have such an umbrella code of nomenclature principles that would apply to all of biology. A need was also recognized for a detailed code, including examples, that is specific to bacteriology, with, presumably, comparable detailed codes specific to other biological disciplines. The existing Bacteriological Code is the product of decades of fine-tuning in response to encounters with specific nomenclature problems and appears to be a successful one, as judged by the general decline in the number of problems brought to the Judicial Commission for resolution. Where applicable, concordance tables would be useful for terminology that is unique to the individual detailed codes.

The new Rules Revision Committee was appointed and consists of P. H. A. Sneath, D. Jones, P. A. D. Grimont, and M. Goodfellow.

Minute 10. Report by the editor of the IJSB. E. Stackebrandt reported that approximately $60 \%$ of all validly described species of bacteria and $68 \%$ of all new yeast species are published in the IJSB. Currently, $56 \%$ of all manuscripts submitted are 
from Europe, $19 \%$ are from the United States, and $10 \%$ are from Japan. The editors who have left the IJSB during 1995 include Herman Phaff, James Staley, and Robert Gherna. The new editors added during 1995 included Monique Gillis, David Labeda, Jan Ursing, and Willam Whitman. The Validation List for new names and combinations published outside of the IJSB and the Notification List are now being compiled by Norbert Weiss.

In discussing the Editor's report, the problem of validation of names that were previously proposed in journals other than the IJSB was raised, particularly in regard to monitoring the quality of those papers. The Judicial Commission has little authority in this regard and serves mainly exemplary and advisory functions. R. Colwell noted that whole genome sequencing will begin impacting taxonomy and that the Commission and the IJSB should begin considering the implications. $M$. Goodfellow suggested that an ad hoc committee consider the impact. The Commission also discussed the financial problems of the IJSB. There was general resistance to initiating page charges, but there was agreement that it would be desirable to broaden the base of subscribers and advertisers. Phylogeny is now a significant and increasing portion of the journal's content, and incorporation of the term into the journal title might expand its base. No action was taken because this is the responsibility of the parent ICSB.

Minute 11. Opinion awarded since the 1994 meeting. Opinion 68 was awarded since the 1994 meeting in Prague, and Pediococcus acidlactici was conserved with a new neotype. (Int. J. Syst. Bacteriol. 46:835, 1996).

Minute 12. Requests for opinions that were denied. No requests for opinions have been denied since the 1994 Meeting.

Minute 13. Pending requests for opinions and related matters. The proposal of Wilhelm and Collins (Int. J. Syst. Bacteriol. 44:591-593, 1994) that the genus name Clostridium should be conserved over the genus name Sarcina after some future revision of the genus Clostridium, because of the effect of the placement of Sarcina ventriculi and Sarcina maxima within Clostridium based on 16S rRNA sequence data, was denied because the majority of the Commission felt that it was inappropriate to render a presumptive opinion on an event (i.e., the revision of Clostridium) which has not yet taken place.

The proposal by Olsen et al. to reject Clostridium putrificum and conserve Clostridium botulinim and Clostridium sporogenes (Int. J. Syst. Bacteriol. 45:414, 1995) was unanimously approved and will be published as Opinion 69.
Several other proposals, including the D. Brenner et al. proposal for the replacement of NCTC 4175 with ATCC 29905 as the type strain of Proteus vulgaris (Int. J. Syst. Bacteriol. 45:870-871, 1995), the Dicks et al. proposal for the reclassification of Lactobacillus casei subspecies casei ATCC 393 and $L$. rhamnosus ATCC 15820 as L. zeae and rejection of $L$. paracase $i$ (Int. J. Syst. Bacteriol. 46:337-340, 1996), and the Tao et al. proposal to correct the irregularities in the validation of the genus Thermodesulfobacterium and its species (Int. J. Syst. Bacteriol. 46:622, 1996) were discussed briefly but were not ready to be voted upon at this time.

Minute 14. Taxonomic subcommittees: comments by Secretary for Subcommittees. The minutes of 20 Subcommittees have been published since the 1994 meeting, and 5 Subcommittees have drafted minimal descriptive standards, including the Subcommittees on the Halobacteriaceae, Arthrobacter, Microbacteria, Pseudomonas, and Bacillus. An update of the lists for membership in all of the Subcommittees is needed, and more coordination of the organization of Subcommittee meetings may also be necessary.

Minute 15. Adjournment. Session 1 was adjourned at 5:00 p.m. on 17 August 1996.

Minute 16. Call to order. The meeting was called to order at 2:50 p.m. on 22 August 1996.

Minute 17. Announcement of new commissioners appointed by the ICSB. Members of the 20th class of commissioners had been elected by the ICSB. The new commission takes office after this meeting and consists of the following individuals: 18th class members D. Jones, R. M. Kroppenstedt, F. Portaels, and G. A. Zavarzin; 19th class members R. R. Colwell, M. Goodfellow (also new Secretary for Subcommittees, ICSB), H. Prauser, and J. T. Staley; and 20th class members P. A. D. Grimont, J. M. Young, H. G. Trüper, and N. Weiss. Minute 18. Election of Chairman and Vice-Chairmen of $J u$ dicial Commission. H. G. Trüper (20th class) was elected as Chairman and J. T. Staley (19th class) was elected as ViceChairman for the balance of their respective terms.

Minute 19. Discharge of retiring 17th class of commissioners. The commission thanked the retiring 17th class of commissioners, P. A. D. Grimont, W. E. C. Moore, L. G. Wayne, and J. M. Young, for their service.

Minute 20. Adjournment. Session 2 was adjourned at 2:56 p.m. on 22 August 1996.

David P. Labeda, Executive Secretary 